\title{
HUBUNGAN RIWAYAT PENYAKIT ISPA DAN DIARE DENGAN STATUS GIZI PADA ANAK USIA 1 - 5 TAHUN
}

\author{
Ratna Indriati, Sri Aminingsih
}

AKPER PANTI KOSALA SURAKARTA, Sukoharjo, Jawa Tengah, Indonesia

\begin{abstract}
Abstrak
Latar Belakang. Kurang gizi pada anak dapat mempengaruhi tumbuh kembang. Penyakit infeksi juga banyak berhubungan dengan kekurangan gizi, diantaranya diare dan ISPA dimana kondisi ini masih terjadi di Posyandu Kusuma Desa Palur.

Tujuan Penelitian. Mengetahui hubungan riwayat ISPA dan diare dengan status gizi anak Subjek dan Metode. Subjek adalah 47 anak usia $1-5$ tahun di Posyandu Kusuma Desa Palur. Jenis penelitian observasi analitik, desain korelasi dan metode cross sectional. Pengambilan sampel secara accidental dan data dianalisis menggunakan uji Chi Square. Hasil Penelitian. Anak dengan riwayat diare 8 anak (17\%), tidak ada riwayat diare 39 anak (83\%), riwayat ISPA 16 anak (34\%), tidak ada riwayat ISPA 31 anak (66\%). Anak dengan status gizi baik 34 anak $(72,3 \%)$, status gizi kurang 13 anak $(27,7 \%)$. Hasil analisis hubungan riwayat diare diperoleh $p=0,001$ dan riwayat penyakit ISPA diperoleh $p=0,693$ terhadap status gizi.

Kesimpulan. Terdapat hubungan yang bermakna riwayat diare dengan status gizi anak $(p=0,001)$ tapi tidak terdapat hubungan riwayat ISPA dengan status gizi anak $(p=0,693)$.
\end{abstract}

Kata kunci : ISPA, riwayat diare, status gizi

\section{THE RELATIONSHIP BETWEEN THE HISTORY OF ACUTE RESPIRATORY INFECTIONS AND DIARRHEA WTH THENUTRTIONAL STATUS OFCHILDREN 1-5 YEARS OLD}

\begin{abstract}
Background. Malnutrition in children can affect growth and development. Infectious diseases are also associated with malnutrition, including diarrhea and Acute Respiratory Infections where this condition still occurs in Posyandu Kusuma, Palur Village.

The Aim of the Study. To find the relationship between the history of acute respiratory infections and diarrhea with the nutritional status of children.

Subject and Method. Subject were 47 of children 1-5 years old in Posyandu Kusuma at Palur Village. This research was observational analytic and correlation design with cross sectional method. Sampling by accidental sampling. The data obtained were analyzed using the Chi Square test.

Result. The children with a history of diarrhea were $8(17 \%), 39$ with no history of diarrhea (83\%), 16 with history of acute respiratory infections (34\%), 31 with no history of acute respiratory infections (66\%). The Childrens with good nutritional status were 34 (72.3\%), 13 underweight nutritional status (27.7\%). The results showed that the relationship of diarrhea history obtained $p=0.001$ and a history of Acute Respiratory Infections obtained $p=0.693$ to nutritional status.

Conclusion. History of diarrhea has a significant relationship with the nutritional status of children $(p=0.001)$ and a history of acute respiratory infections has no relationship with the nutritional status of children $(p=0.693)$.
\end{abstract}

Keywords : diarrhea, history of acute respiratory infections, nutritional status.

Korespondensi: Ratna Indriati. AKPER PANTI KOSALA SURAKARTA. Jalan Raya SoloBaki Km. 4 Gedangan, Grogol, Sukoharjo, Jawa Tengah. Email: ratna24173@gmail.com. 


\section{PENDAHULUAN}

Masalah gizi pada anak masih menjadi salah satu masalah kesehatan di Indonesia yang perlu diatasi. Berdasarkan hasil Riset Kesehatan Dasar Kementerian kesehatan tahun 2018 menunjukkan $17,7 \%$ balita masih mengalami masalah gizi. Keadaan kurang gizi pada anak dapat mempengaruhi tumbuh kembang anak sehingga anak akan tumbuh menjadi manusia yang tidak berkualitas sedangkan anak merupakan generasi penerus bangsa yang berperan dalam keberhasilan pembangunan.

Sasaran dari program Indonesia sehat adalah meningkatnya derajat kesehatan dan status gizi masyarakat, sehingga dalam kurun waktu 2015 - 2019 sektor kesehatan salah satunya diarahkan untuk memfokuskan upaya guna menurunkan prevalensi balita pendek/stunting (Kemenkes RI, 2017). Adapun prevalensi balita yang mengalami stunting sebesar 30,8\% (Riskesdas, 2018). Stunting merupakan masalah gizi kronis yang disebabkan oleh asupan gizi kurang dalam waktu lama. Untuk menurunkan prevalensi balita dengan stunting maka anak dengan kurang gizi harus diatasi secara dini serta sangat penting mengenali faktor - faktor yang mempengaruhi status gizi pada balita sehingga bisa mencegah kurang gizi pada anak.

Faktor - faktor yang mempengaruhi status gizi pada balita menurut Septikasari (2018), meliputi asupan gizi kurang, pola asuh yang tidak memadai, produksi pangan yang kurang, sanitasi air bersih/pelayanan kesehatan dasar yang tidak memadai serta faktor penyakit infeksi.

Anak yang mengalami penyakit infeksi dapat menyebabkan rusaknya beberapa fungsi organ tubuh sehingga tidak bisa menyerap zat - zat makanan secara baik, hal ini yang menyebabkan anak mengalami masalah dalam asupan makanan sehingga berpengaruh pada kecukupan gizi anak.

Penyakit infeksi merupakan penyakit yang banyak berhubungan dengan terjadinya kekurangan gizi di negara berkembang. Infeksi yang sering terjadi pada anak adalah penyakit saluran pernafasan atas, bawah, diare dan kulit (Istiany dan Rusilanti, 2013).

Infeksi Saluran Pernapasan Akut (ISPA) adalah penyakit saluran pernapasan yang bersifat akut dengan berbagai macam gejala (sindrom). Penyakit ini disebabkan oleh berbagai sebab (multifaktorial). Meskipun organ pernapasan yang terlibat adalah hidung, laring, tenggorok, bronkus, trakhea dan paru - paru, tetapi yang menjadi fokus adalah paru - paru. Titik perhatian ini disepakati karena tingginya tingkat mortalitas radang paru - paru/pneumonia (Widoyono, 2011).

Diare adalah pengeluaran kotoran (tinja) dengan frekuensi yang meningkat (lebih dari 3x dalam 24 jam) disertai dengan perubahan konsistensi tinja menjadi lembek atau cair (Wijoyo, 2013).

Diare dapat menyebabkan kehilangan banyak cairan dan elektrolit melalui feses (Sodikin, 2011). Menurut Wijoyo (2013), kejadian diare akan menyebabkan gangguan gizi akibat intake asupan makanan yang berkurang, demikian pula menurut Dermawan dan Rahayuningsih (2010), salah satu komplikasi dari diare adalah malnutrisi.

Penelitian yang dilakukan oleh Setyorini (2012), menunjukkan ada hubungan kesakitan ISPA dengan status gizi anak ( $p$ value $=0,001)$ dan ada hubungan antara diare dengan status gizi anak ( $p$ value = 0,000 ). Penyakit infeksi akan mempengaruhi asupan makan seseorang. Asupan makan yang kurang baik dapat mempengaruhi 
status gizi anak, hal ini seperti penelitian yang dilakukan oleh Rachmayani, Kuswari dan Melani (2018), yang menunjukkan terdapat hubungan yang signifikan antara asupan energi dengan status gizi ( $p$ value $=0,001)$, antara asupan protein dengan status gizi remaja ( $p$ value $=0,027$ ) dan antara asupan karbohidrat dengan status gizi $(p=$ 0,029).

Penelitian lain yang dilakukan oleh Sholikah, Rustiana dan Yuniastuti (2017), menunjukkan faktor yang berhubungan dengan status gizi pada balita di pedesaan dan perkotaan adalah penyakit infeksi ( $p$ value $=0,048$ ), dan penyakit infeksi yang paling banyak dialami balita dalam penelitian adalah tuberculosis, diare dan ISPA. Demikian juga penelitian yang dilakukan oleh Betan, Hemcahayat dan Wetasin (2018), menunjukkan ada hubungan antara kejadian dan frekuensi penyakit infeksi (penyakit diare dan atau infeksi saluran pernafasan) dengan malnutrisi pada anak ( $p$ value $=0,001)$.

Penelitian ini merupakan replikasi dari penelitian sebelumnya namun terdapat perbedaan lokasi penelitian sehingga dengan wilayah yang berbeda dimungkinkan ada perbedaan pada karakteristik responden.

Posyandu Kusuma merupakan posyandu balita di Desa Palur, dimana jumlah kunjungan balita lebih dari 45 anak setiap bulannya. Di Posyandu Kusuma selama ini belum pernah dilakukan penelitian mengenai riwayat penyakit ISPA dan diare yang mempengaruhi status gizi anak balita. Maka penulis tertarik untuk melakukan penelitian tentang "Hubungan Riwayat Penyakit ISPA dan Diare dengan Status Gizi pada Anak Usia $1-5$ Tahun".

\section{TUJUAN PENELITIAN}

Tujuan penelitian untuk mengetahui hubungan antara riwayat penyakit ISPA dengan status gizi anak usia 1-5 tahun dan riwayat diare dengan status gizi anak usia 1-5 tahun.

\section{METODE}

Penelitian ini merupakan penelitian analitik observasional dengan desain korelasi. Lokasi penelitian di Posyandu Kusuma Desa Palur Sukoharjo. Pengumpulan data dengan menggunakan kuesioner dan data yang sudah terkumpul dianalisis menggunakan uji Chi Square.

\section{SUBJEK}

Subyek penelitian adalah anak usia 1-5 tahun di Posyandu Kusuma Desa Palur Sukoharjo, pengambilan sampel menggunakan teknik accidental sampling dengan jumlah sampel 47 responden.

\section{HASIL PENELITIAN}

Berdasarkan penelitian yang telah dilakukan didapatkan karakteristik responden berdasarkan jenis kelamin responden, umur responden dan pekerjaan ibu dari responden beserta hasil penelitian mengenai hubungan riwayat penyakit ISPA dan diare dengan status gizi anak usia 1-5 tahun, yaitu sebagai berikut :

Tabel 1.

Distribusi Frekuensi

Karakteristik Responden

\begin{tabular}{lcc}
\hline \multicolumn{1}{c}{ Karakteristik } & $\mathrm{f}$ & $\%$ \\
\hline $\begin{array}{l}\text { Jenis kelamin anak } \\
\text { Laki-laki }\end{array}$ & 24 & 51,1 \\
Perempuan & 23 & 48,9 \\
Umur & & \\
1-3 tahun & 36 & 76,6 \\
>3-5 tahun & 11 & 23,4 \\
Pekerjaan orang tua & & \\
PNS & 2 & 4,3 \\
Swasta/Wiraswasta & 20 & 42,5 \\
Tidak bekerja & 25 & 53,2 \\
\hline
\end{tabular}


Dari Tabel 1 di atas diperoleh informasi bahwa jumlah responden dengan jenis kelamin laki - laki lebih besar yaitu 24 anak $(51,1 \%)$, umur anak lebih banyak pada kelompok umur 1 - 3 tahun yaitu 36 anak $(76,6 \%)$ dan sebagian besar orang tua (ibu) tidak bekerja/ibu rumah tangga sebanyak 25 ibu $(53,2 \%)$.

Tabel 2.

Distribusi Frekuensi Riwayat ISPA, Diare dan Status Gizi Anak

\begin{tabular}{lcc}
\multicolumn{3}{c}{ Diare dan Status Gizi Anak } \\
\hline \multicolumn{1}{c}{ Variabel } & $\mathrm{f}$ & $\%$ \\
\hline Riwayat ISPA & & \\
Ada & 16 & 34 \\
Tidak ada & 31 & 66 \\
& & \\
Riwayat Diare & & \\
Ada & 8 & 17 \\
Tidak ada & 39 & 83 \\
& & \\
Status Gizi Anak & & \\
Baik & 34 & 72,3 \\
Kurang & 13 & 27,7 \\
\hline
\end{tabular}

Dari Tabel 2 di atas dapat dicermati bahwa anak dengan riwayat penyakit ISPA sejumlah 16 anak $(34 \%)$ lebih sedikit dibandingkan dengan anak yang tidak memiliki riwayat ISPA yaitu 31 anak (66\%), sebagian besar anak tidak memiliki riwayat diare yaitu 39 anak $(83 \%)$ dan 8 anak $(17 \%)$ memiliki riwayat diare. Anak dengan status gizi baik sebanyak 34 anak (72,3\%) lebih banyak dibandingkan dengan anak yang status gizinya kurang yaitu 13 anak $(27,7 \%)$.

Tabel 3.

Tabulasi Silang Riwayat ISPA dan Status Gizi Anak

\begin{tabular}{ccccc}
\hline \multirow{2}{*}{$\begin{array}{c}\text { Riwa } \\
\text { yat }\end{array}$} & \multicolumn{2}{c}{ Status Gizi } & Total & $\mathrm{p}$ \\
\cline { 2 - 3 } ISPA & $\begin{array}{c}\text { Kurang } \\
(\%)\end{array}$ & $\begin{array}{c}\text { Baik } \\
(\%)\end{array}$ & $(\%)$ & \\
\hline Ada & 5 & 11 & 16 & 0,69 \\
& $(31,3)$ & $(68,7)$ & $(100)$ & 3 \\
& & & & \\
Tidak & 8 & 23 & 31 & \\
ada & $(25,8)$ & $(74,2)$ & $(100)$ & \\
\hline Total & 13 & 34 & 35 & \\
& $(27,7)$ & $(72,3)$ & $(100)$ & \\
\hline
\end{tabular}

Dari hasil uji Chi Square dengan tingkat signifikasi $\alpha=0,05$ diperoleh nilai $p$ sebesar 0,693 . Karena nilai $p$ $>0,05$ hipotesis ditolak yang berarti tidak ada hubungan antara riwayat penyakit ISPA dengan status gizi anak.

Tabel 4

Tabulasi Silang Riwayat Diare dan Status Gizi Anak

\begin{tabular}{ccccc}
\hline \multirow{2}{*}{$\begin{array}{c}\text { Riwayat } \\
\text { Diare }\end{array}$} & \multicolumn{3}{c}{ Status Gizi } & \\
& $\begin{array}{c}\text { Kura } \\
\text { ng } \\
(\%)\end{array}$ & $\begin{array}{c}\text { Baik } \\
(\%)\end{array}$ & $\begin{array}{c}\text { Total } \\
(\%)\end{array}$ & $\mathrm{p}$ \\
\hline Ada & 6 & 2 & 8 & 0,001 \\
& $(75)$ & $(25)$ & $(100)$ & \\
Tidak & 7 & 32 & 39 & \\
ada & $(18)$ & $(82)$ & $(100)$ & \\
\hline Total & 13 & 34 & 35 & \\
& $(27,7)$ & $(72,3)$ & $(100)$ & \\
\hline
\end{tabular}

Dari hasil uji Chi Square dengan tingkat signifikasi $\alpha=0,05$ diperoleh nilai $p$ sebesar 0,001 . Karena nilai $p$ $<0,05$ hipotesis diterima yang berarti ada hubungan riwayat diare dengan status gizi anak dan $\mathrm{OR}=13,71$ yang menunjukkan anak yang memiliki riwayat diare berisiko 13,71 kali mengalami status gizi kurang.

\section{PEMBAHASAN}

ISPA (Infeksi Saluran Pernafasan Akut) merupakan penyakit saluran pernafasan yang bersifat akut dengan berbagai macam gejala atau sindrom (Widoyono, 2011). Penyakit ISPA bisa mengenai saluran pernafasan atas dan atau saluran pernafasan bawah. Pada variabel riwayat penyakit ISPA dari balita di Posyandu Kusuma, dari tabel 2 diperoleh informasi terdapat 16 anak $(34 \%)$ yang memiliki riwayat penyakit ISPA dalam 1 bulan terakhir dimana frekuensi mengalami penyakit ISPA adalah $1 \mathrm{x}$ - 2x dan 31 anak (66\%) tidak memiliki riwayat penyakit ISPA. Dari 16 anak yang mengalami ISPA $62,5 \%$ anak berusia $1-3$ tahun. Hal ini sesuai dengan teori yang dipaparkan oleh Hartono dan 
Rahmawati (2016), bahwa usia anak lebih rentan untuk mengalami Infeksi saluran pernafasan bagian atas oleh karena rendahnya sistem kekebalan pada anak sehingga berisiko terinfeksi. Hasil penelitian yang dilakukan oleh Iskandar, Tanuwijaya dan Yuniarti (2015), menunjukkan anak usia 1 - 3 tahun lebih berisiko 1,77 kali terkena ISPA dibandingkan dengan anak usia 3 5 tahun. Dari hasil penelitian ini terdapat 16 anak yang mengalami penyakit ISPA dimana berdasarkan gejala yang muncul seluruh anak menunjukkan gejala batuk pilek, tidak ada yang mengalami sesak nafas serta tidak ada yang dirawat di rumah sakit. Dari hasil penelitian tersebut menunjukkan gejala ISPA yang dialami anak cenderung pada klasifikasi ISPA bukan pneumonia. Menurut Widoyono (2011), klasifikasi ISPA meliputi ISPA bukan pneumonia (common cold, faringitis, tonsillitis dan otitis), mencakup kelompok pasien balita dengan batuk yang tidak menunjukkan gejala peningkatan frekuensi pernafasan dan tidak menunjukkan adanya tarikan dinding dada bagian bawah ke dalam dan ISPA dengan pneumonia yang didasarkan pada adanya batuk dan atau kesukaran bernafas disertai sesak nafas atau tarikan dinding dada bagian bawah ke arah dalam (chest indrawing). ISPA bukan pneumonia merupakan infeksi saluran pernafasan akut yang mengenai saluran pernafasan bagian atas yang meliputi hidung dan faring.

Hasil uji Chi Square dengan tingkat signifikansi $\alpha=0,05$ antara riwayat penyakit ISPA dengan status gizi anak diperoleh $p$-value sebesar $0,6931 \quad(p>0,05)$, hal ini menunjukkan tidak ada hubungan antara riwayat penyakit ISPA dengan status gizi anak usia $1-5$ tahun di Posyandu Kusuma.

Penelitian ini menunjukkan hasil yang sama dengan penelitian
Khuriyah (2017), yaitu tidak ada hubungan riwayat penyakit ISPA dengan status gizi anak di Wilayah Kerja Puskesmas Kaliwungu Kabupaten Kudus $(p=0,678)$. Penelitian ini juga menunjukkan hasil yang sama dengan penelitian Putri, Kapantow dan Kawengian (2015), yaitu tidak terdapat hubungan antara penyakit infeksi dengan status gizi anak umur 1-3 tahun di Desa Mopusi Kecamatan Loloyan Kabupaten Bolaang Mongondow Induk $(p=0,372)$.

Sementara penelitian yang lain menunjukkan bertentangan dengan penelitian ini yang dilakukan oleh Rifki (2018), terdapat hubungan antara Riwayat ISPA dan status gizi pada balita di wilayah kerja Puskesmas Jepang Kudus $(0,000)$. Hasil dari penelitian ini menunjukkan tidak terdapat hubungan antara penyakit ISPA dengan status gizi. Meskipun penyakit infeksi (salah satunya penyakit ISPA) merupakan salah satu faktor yang mempengaruhi status gizi anak akan tetapi berdasarkan informasi gejala ISPA yang dialami oleh responden yaitu batuk pilek tanpa disertai sesak nafas, hal inilah yang kemungkinan menyebabkan penyakit ISPA yang dialami responden kurang berpengaruh pada status gizi. Di samping itu juga masih terdapat faktor-faktor lain yang mempengaruhi status gizi pada anak usia $1-5$ tahun di Posyandu Kusuma Desa Palur diantaranya pola asuh dalam keluarga, sosiodemografi, ketersediaan pangan, sanitasi lingkungan dan pelayanan kesehatan dasar. Untuk itu perlu dilakukan penelitian lain mengenai faktor - faktor yang mempengaruhi status gizi pada anak.

Diare merupakan buang air besar dengan frekuensi yang meningkat (lebih dari 3x dalam 24 jam) disertai dengan perubahan konsistensi feses menjadi lembek atau cair, 
dengan atau tanpa darah/ lendir dalam feses (Wijoyo, 2013). Dari Tabel 2 diperoleh informasi responden yang memiliki riwayat diare dalam 1 (satu) bulan terakhir sejumlah 8 anak (17\%). Penyebab dari diare diantaranya karena faktor infeksi saluran pencernaan yang merupakan penyebab utama atau faktor malabsorbsi dan faktor makanan (Dermawan dan Rahayuningsih, 2010). Diare lebih banyak terjadi pada usia balita dimana daya tahan tubuh balita yang lemah atau menurun. Aspek yang paling banyak menyebabkan terjadinya diare pada balita yaitu infeksi mikroorganisme yang jumlahnya berlebih dan patogenik, yang bisa masuk ke tubuh anak dipengaruhi oleh faktor lingkungan maupun perilaku yang kurang sehat (Ariani, 2016). Seperti penelitian yang dilakukan oleh Melvani, Zulkifli dan Faizal (2019), menunjukkan bahwa faktor sanitasi makanan dan minuman berhubungan secara signifikan dengan kejadian diare pada balita $(p=0,000)$. Demikian pula responden dalam penelitian ini berada pada usia 1-5 tahun dimana berdasarkan usia masih sangat rentan untuk mengalami diare.

Berdasarkan analisa statistik dengan uji Chi Square antara riwayat diare dengan status gizi anak diperoleh $p$-value sebesar $0,001 \quad(p<0,05)$, hal ini menunjukkan ada hubungan antara riwayat diare dengan status gizi anak usia 1 - 5 tahun di Posyandu Kusuma, dengan OR 13,71 menunjukkan anak dengan diare memiliki risiko 13,71 kali untuk mengalami status gizi kurang. Dari 8 (delapan) anak yang mempunyai riwayat diare, $75 \%$ anak memiliki status gizi kurang dan $25 \%$ memiliki status gizi baik. Sedangkan dari 39 anak yang tidak mempunyai riwayat diare $18 \%$ anak memiliki status gizi kurang dan $82 \%$ status gizi baik.
Dampak dari diare pada anak salah satunya adalah anak mengalami gangguan gizi yang bisa terjadi karena masukan makanan berkurang (adanya anoreksia) serta gangguan absorbsi (Ariani, 2016). Orang tua yang mengetahui anaknya mengalami diare biasanya akan menghentikan beberapa macam makanan oleh karena ketidaktahuan atau karena anak tidak mau makan/mengalami penurunan nafsu makan serta bisa disertai muntah pada anak (Wijoyo, 2013). Kondisi tersebut bisa mempengaruhi asupan makanan pada anak. Demikian juga pada diare akut sering disertai malabsorbsi dari nutrien baik mikro maupun makro. Anak bisa mengalami malabsorbsi terhadap karbohidrat, lemak, protein atau bisa juga terhadap vitamin dan mineral. Diare bisa mengganggu absorbsi dikarenakan adanya kerusakan permukaan epitel atau kerusakan mukosa usus dimana akan terjadi perubahan struktur mukosa usus dan kemudian terjadi pemendekan villi dan pendangkalan kripta yang menyebabkan berkurangnya permukaan mukosa usus (Ariani, 2016). Selain malabsorbsi, diare juga bisa mempengaruhi metabolisme yang dapat menyebabkan peningkatan kebutuhan energi serta kehilangan protein selama diare melalui saluran pencernaan. Berbagai kondisi tersebut akan mempengaruhi kecukupan gizi pada anak sehingga status gizi anak menjadi kurang bahkan bisa dalam status gizi buruk. Hal ini seperti penelitian yang dilakukan oleh Andrian (2018), yang menunjukkan ada hubungan antara diare dengan status gizi balita $(p=0,036)$, dimana dari 39 kasus anak dengan diare prevalensi status gizi buruk sebanyak $51,3 \%$, gizi baik $33,3 \%$ dan gizi lebih $15,4 \%$. Dari hasil tersebut menunjukkan prevalensi gizi buruk lebih banyak 
ditemukan pada anak yang mengalami diare. Penelitian lain yang dilakukan oleh Sampul, Ismanto dan Pondaag (2015), juga menunjukkan terdapat hubungan yang bermakna antara diare dengan kejadian malnutrisi pada balita $(p=0,000)$. Demikian juga yang dialami oleh responden dalam penelitian ini, dimana responden berada pada rentang usia $1-5$ tahun, pada usia tersebut anak biasanya membutuhkan pemantauan untuk pemenuhan gizi dengan karakter anak yang suka memilih makanan dan belum mengerti pentingnya gizi seimbang sehingga dengan diare yang dialami semakin mengurangi asupan gizi yang dibutuhkan oleh anak yang sedang dalam masa tumbuh kembang. Hal ini dimungkinkan menjadi penyebab dari status gizi kurang yang dialami oleh responden.

Status gizi adalah keadaan tubuh manusia sebagai akibat konsumsi makanan dan penggunaan zat - zat gizi yang dikategorikan menjadi 3 (tiga) yaitu gizi lebih, gizi baik dan gizi buruk (Mardalena, 2017). Data status gizi anak balita di Posyandu Kusuma Kelurahan Palur menunjukkan dari 47 anak usia 1 5 tahun dijumpai 13 anak $(27,7 \%)$ memiliki status gizi kurang dan 34 anak $(72,3 \%)$ memiliki status gizi baik. Meskipun sebagian besar anak sudah memiliki status gizi baik namun masih ada anak yang memiliki status gizi kurang. Dengan status gizi kurang tersebut apabila tidak segera diberi intervensi yang tepat maka akan bisa berlanjut menjadi status gizi buruk. Demikian pula anak yang sudah memiliki status gizi baik perlu tetap dipertahankan sehingga perlu dianalisa berbagai faktor yang mempengaruhi status gizi pada anak. Menurut Septikasari (2018), ada beberapa faktor yang mempengaruhi status gizi seseorang diantaranya terbatasnya asupan makanan yang dikonsumsi dan penyakit infeksi dimana salah satu penyakit infeksi yang sering dialami oleh anak adalah diare. Asupan makanan yang terbatas tersebut bisa terjadi pada anak yang mengalami diare. Demikian juga menurut Mardalena (2017), baik buruknya status gizi manusia dipengaruhi oleh 2 (dua) hal pokok yaitu konsumsi makanan dan keadaan kesehatan tubuh atau infeksi.

Status gizi yang kurang pada anak perlu diwaspadai mengingat anak pada usia 1 - 5 tahun sedang dalam periode tumbuh kembang. Pada periode ini sangat diperlukan adanya lingkungan yang mendukung baik internal maupun eksternal dan salah satu faktor yang sangat penting adalah gizi. Status gizi yang kurang atau buruk pada anak akan mengganggu pertumbuhan dan perkembangan anak. Dan dari hasil penelitian ini menunjukkan pada kelompok anak yang mengalami diare $75 \%$ memiliki status gizi kurang, dari data ini bisa dianalisa bahwa diare pada anak bisa mempengaruhi status gizi anak menjadi kurang sehingga perlu dilakukan upaya untuk mencegah terjadinya diare pada anak. Namun dalam penelitian ini masih ada $25 \%$ anak yang mengalami diare akan tetapi tetap memiliki status gizi baik. Hal ini dimungkinkan karena masih ada faktor lain yang mempengaruhi status gizi seperti asupan makanan, pola asuh, ketersediaan pangan dan sanitasi/pelayanan kesehatan dasar yang tidak dibahas dalam penelitian ini, serta pada saat anak mengalami diare asupan nutrisi anak bisa dipengaruhi oleh frekuensi diare, lama diare dan munculnya anoreksia pada anak. Untuk itu perlu dilakukan penelitian lebih lanjut mengenai faktor-faktor tersebut. 


\section{KESIMPULAN}

Berdasarkan hasil penelitian diperoleh kesimpulan bahwa riwayat ISPA tidak memiliki hubungan dengan status gizi anak $(p=0,693)$ dan riwayat diare memiliki hubungan dengan status gizi anak $(p=0,001)$ dengan $\mathrm{OR}=13,71 \quad$ yang menunjukkan anak dengan diare memiliki risiko 13,71 kali untuk mengalami status gizi kurang.

\section{SARAN}

Orang tua diharapkan menerapkan PHBS (Perilaku Hidup Bersih dan Sehat) untuk mencegah terjadinya diare pada anak dan anak yang mengalami diare harus diberikan penatalaksanaan yang tepat seperti asupan nutrisi yang adekuat selama sakit untuk menjaga status gizinya. Bagi Kader Posyandu diharapkan senantiasa berkolaborasi dengan pihak Puskesmas untuk memberikan pendidikan kesehatan pada masyarakat tentang pencegahan penyakit infeksi pada anak dan faktor yang mempengaruhi status gizi anak.

\section{DAFTAR PUSTAKA}

Andrian. 2018. Hubungan Diare dengan Status Gizi pada Balita di Rumah Sakit Universitas Sumatera Utara. Skripsi. URL : http://repositori.USU.ac.id./ handle/123456789/13488.

Diakses tanggal 8 April 2020.

Ariani, A. P. 2016. Diare Pencegahan dan Pengobatannya. Nuha Medika, Yogyakarta.

Betan, Y., M. Hemcahayat dan K. Wetasin. 2018. "Hubungan antara Penyakit Infeksi dan Malnutrisi pada Anak $2-5$ Tahun." Jurnal Ners LENTERA. 6.1. STIKES Citra Husada Mandiri. Kupang. Diakses tanggal 4 September 2019.

Dermawan, D. dan T. Rahayuningsih. 2010.
Keperawatan Medikal Bedah (Sistem Pencernaan). Gosyen Publishing, Yogyakarta.

Hartono, R. dan D. Rahmawati. 2012. ISPA Gangguan Pernafasan pada Anak. Nuha Medika, Yogyakarta.

Iskandar, A., S. Tanuwijaya dan L. Yuniarti. 2015. "Hubungan Jenis Kelamin dan Usia Anak $1-5$ tahun dengan Kejadian ISPA." Global Medical and Health Communication. 3.1 . Universitas Islam, Bandung. Diakses tanggal 7 April 2020.

Istiany, A. dan Rusilanti. 2013. Gizi Terapan. PT Remaja Rosdakarya, Bandung.

Kemenkes RI. 2017. Rencana Strategis Kementerian Kesehatan tahun 2015 - 2019. Kemenkes, Jakarta.

Khuriyah, N. 2017. "Hubungan antara Riwayat Penyakit ISPA dan Diare dengan Status Gizi pada Anak di Wilayah Kerja Puskesmas Kaliwungu Kabupaten Kudus." Prosiding HEFA. 3. STIKES Cendekia Utama Kudus. Diakses tanggal 14 April 2020.

Mardalena, I. 2017. Dasar - dasar IImu Gizi dalam Keperawatan Konsep dan Penerapan pada Asuhan Keperawatan. Pustaka Baru Press, Yogyakarta.

Melvani, R. P., H. Zulkifli dan M. Faizal. 2019. "Analisis Faktor yang Berhubungan dengan Kejadian Diare Balita di Kelurahan Karyajaya Kota Palembang." Jurnal JUMANTIK. 4.1. Universitas Sriwijaya. Diakses tanggal 7 April 2020.

Putri, M. S., N. Kapantow dan S. Kawengian. 2015. "Hubungan antara Riwayat Penyakit Infeksi dengan Status Gizi pada Anak Balita di Desa Mopusi Kecamatan Lolayan Kabupaten Bolaang Mongondow." Jurnal eBiomedik (eBm). 3.2. Universitas Sam Ratulangi, 
Manado. Diakses tanggal 8 April 2020.

Rachmayani, S. A., M. Kuswari dan V. Melani. 2018. "Hubungan Asupan Zat Gizi dan Status Gizi Remaja Putri di SMK Ciawi Bogor." Indonesian Journal of Human Nutrition.5.2. Universitas Esa Unggul. Jakarta. Diakses tanggal 4 September 2019.

Rifki, F. M. 2018. "Hubungan Riwayat ISPA dengan Status Gizi pada Balita di Wilayah Kerja Puskesmas Jepang Kudus." Prosiding HEFA.3. STIKES Cendekia Utama Kudus. Diakses tanggal 7 April 2020.

Riskesdas. 2018. Hasil Utama Riskesdas Badan Penelitian dan Pengembangan Kesehatan. Kementerian Kesehatan RI, Jakarta. www.depkes.go.id. Diakses pada tanggal 22 September 2019.

Sampul, M. P. K, A. Y. Ismanto dan L. Pondaag. 2015. "Hubungan Diare dengan Kejadian Malnutrisi pada Balita di IRINA E Bawah RSUP Prof. Dr. R.D. Kandou Manado." Jurnal Keperawatan. 3. 1. Universitas Sam Ratulangi, Manado. Diakses tanggal 8 April 2020.
Setyorini, I. D. 2012. Hubungan Kesakitan ISPA dan Diare dengan Status Gizi Anak Balita di Desa Selodoko Kecamatan Ampel Kabupaten Boyolali. Skripsi. Universitas Muhamadiyah Surakarta.

Septikasari, M. 2018. Status Gizi Anak dan Faktor yang Mempengaruhi. UNY Press, Yogyakarta.

Sholikah, A., E. R. Rustiana, A. Yuniastuti. 2017. "Faktor Faktor yang Berhubungan dengan Status Gizi Balita di Pedesaan dan Perkotaan." Public Health Perspective Journal. Universitas Negeri Semarang. Diakses pada tanggal 4 September 2019.

Sodikin. 2011. Asuhan Keperawatan Anak Gangguan Sistem Gastrointestinal dan Hepotobilier. Salemba Medika, Jakarta.

Widoyono. 2011. Penyakit Tropis Epidemiologi, Penularan, Pencegahan \& Pemberantasannya. Erlangga, Jakarta.

Wijoyo, Y. 2013. Diare Pahami Penyakit dan Obatnya. PT Citra Aji Pratama, Yogyakarta. 